Olja Munitlak Ivanović ${ }^{1}$

Neda Raspopović ${ }^{2}$

Petar Mitić ${ }^{3}$

Slobodan Rakić
JEL: G22, G17, E37, C10

DOI: 10.5937/industrija41-4278

UDK: 368.91:339.13(497.11)

Original Scientific Paper

\title{
Analysis of Life Insurance Premium in Regard to Net Income as an Influencing Factor - the Case of the Republic of Serbia ${ }^{5}$
}

\author{
Article history \\ Received: 1 August 2013 \\ Sent for revision:11 October 2013 \\ Received in revised form:22 November2013 \\ Accepted:25 November 2013 \\ Available online:26 November 2013
}

\begin{abstract}
During the last few years, life insurance market in Serbia has had an upward trend, however, it still significantly falls back in comparison to developed European countries. This paper presents a projection of life insurance premium on the basis of linear trend parameters and correlation degree between the average net income and the amount of life insurance premium. Additionally, the necessity of intense development of life insurance market is emphasized. The results indicate that development rate of life insurance market in the Republic of Serbia is not sufficient and that there is a significant influence of net income on the amount of life insurance premium.
\end{abstract}

Keywords: life insurance, insurance market, net income

\section{Analiza premije životnog osiguranja sa osvrtom na neto zaradu kao faktorom uticaja - slučaj Republike Srbije}

Apstrakt: Tržište životnog osiguranja u Srbiji u poslednjih nekoliko godina pokazuje tendenciju rasta, ali još uvek značajno zaostaje u poređenju sa razvijenim evropskim zemljama. $U$ ovom radu je predstavljena projekcija premije životnog osiguranja na osnovu parametara linearnog trenda $i$ stepena korelacije između prosečne neto zarade $i$ veličine premije životnog osiguranja i ukazano je na neophodnost intezivnijeg razvoja tržišta životnog osiguranja.

\footnotetext{
${ }^{1}$ Educons University, Faculty of Business Economy, oljaivanovic@eunet.rs

${ }^{2}$ Educons University, Faculty of Business Economy, neda.raspopovic@gmail.com

${ }^{3}$ Educons University, Faculty of Business Economy, petar.mitic@educons.edu.rs

${ }^{4}$ Educons University, Faculty of Business Economy, rakic@educons.edu.rs

${ }^{5}$ This paper is a part of research projects numbers 47009 and 179015 financed by the Ministry of Science and Technological Development of the Republic of Serbia
} 
Munitlak Ivanović O. et al.: Analysis of Life Insurance Premium in Regard to Net...

Rezultati ukazuju na to da stepen razvoja tržišta životnog osiguranja u Republici Srbiji nije dovoljan i da postoji statistički značajan uticaj neto prihoda na obim premije životnog osiguranja.

Ključne reči: životno osiguranje, tržište osiguranja, neto zarada

\section{Introduction}

Banks dominate domestic financial market, while insurance companies, as financial institutions, have a smaller share of this market. Experience of other countries which went through a transition period, which Republic of Serbia is going through, confirm the fact that development of insurance market takes time and that insurance sector develops after banking sector (Jeremić \& Paunović, 2011).

Although there is a great number of insurance companies, the insurance market has a relatively high concentration degree. In 2011, three companies had a market share of $63,1 \%$, five companies had $25,4 \%(44,8 \%$ of life insurance premiums belong to this group), and fifteen $11,4 \%$. Data from previous years indicate that there is a significant downward trend of concentration degree, which began in 2007 (National Bank of Serbia, 2012). Ever since the beginning of the implementation of Insurance Law in 2004 (Službeni glasnik, 2004) the insurance market in Serbia has been relatively stable, with an upward trend. However it still faces numerous problems.

The most important factors of life insurance are: national income and standard of living; stability of domestic currency; development of social insurance in a country; employment rate and other economic and demographic variables. Among the mentioned factors, monetary stability is especially important, because any change in the purchasing power of money destimulates every form of saving and therefore it represents one of the most significant limiting determinants of life insurance development (Avdalović, 2007).

Identical opinion have Chi-Hung and Chien-Chiang (2012) who emphasize that among economic factors affecting life insurance demand, income level should be the most fundamental factor on the purchase decision for insurance.

Additional confirmation comes from the survey carried out by the reinsurance company Swiss Re in April 2012 for European countries. The aim was to determine users' opinions about the industry of life insurance (Swiss Re, 2012). The main reason for not purchasing insurance in all age groups was the fact that they cannot afford to purchase insurance policy, lack of interest and up to certain extent lack of trust. These reasons can be stated as the key obstacles in the development of life insurance in Serbia. 
Munitlak Ivanović O. et al.: Analysis of Life Insurance Premium in Regard to Net...

The above mentioned circumstances, intensified by the negative influence of global economic crisis, contributed to the fact that the level of life insurance in Republic of Serbia is still low. In the realization of future goals of economic growth and development, life insurance can have significant role both in achieving security of individuals and financing state development as institutional investor. Furthermore, Chi-Hung and Chien-Chiang (2012) point out that the development of the insurance market should not be ignored because, like the banking sector and stock market, it plays an important role in promoting economic growth.

Authors Burnett and Palmer (1984) state that apart from economic variables, important role in making decisions on purchasing life insurance policies also have demographic and psychographic variables, they emphasize that for the insurance markets financial factors are specially important, among which net income is one of the most important.

According to Beck and Webb (2003) estimations show that countries with higher income (both current and permanent), lower inflation, and better developed banks have higher life insurance consumption. Furthermore they state that rising income per capita helps drive life insurance consumption although it is considered as one of the most robust predictors of life insurance consumption across countries and over time.

In accordance with the aforementioned Ward and Zurbruegg (2000) also state that insurance market development may vary across countries because the influence of insurance market development, while channeled through indemnification and financial intermediation, is tempered by country specific factors. So forth, attitudes to risk and the appropriateness of insurance as a risk management technique are likely to be culturally determined and therefore different across economies.

Encouraged by the previous conclusions, the aim of this paper is to show how net income influences the amount of life insurance premium on a particular case of the life insurance market in the Republic of Serbia.

The research is based on the presentation of the life insurance market in the Republic of Serbia and its comparison to the markets in the region. Indicators and characteristics of life insurance market are presented along with the current trends in the market. A regression model is created which shows the impact of net income to the amount of life insurance premium in the Republic of Serbia. This model, together with abstracting other affecting economic, demographic and psychographic variables, indicates positive statistic relation between net income and the amount of life insurance premium. 
Munitlak Ivanović O. et al.: Analysis of Life Insurance Premium in Regard to Net...

\section{Methodology of Research}

The standard methodology for humanities and social sciences was used for this research. Descriptive and comparative methods along with analyses of institutional reports were used to present the situation and tendencies in the life insurance market in the Republic of Serbia. The fundamental part of the research which led the authors to the stated conclusions was based on the mathematical and statistical methods for the purpose of analyzing the variance of time series, as well as correlation and regression analysis. Microsoft Office Excel 2007 was used for data processing.

The analyzed data refer to the period between 2004 and 2011 and describe insurance market in the Republic of Serbia with presentation of fundamental macroeconomic indicators which determine economic development.

Reports and publications which were used as the basis of the descriptive presentation as well as the source of quantitative data are:

- National Bank of Serbia. (2012). Insurance sector in Serbia, report for the 3rd quarter of 2012. Belgrade, Serbia

- National Bank of Serbia. (2012). Insurance sector in Serbia, report for the 2011.Belgrade, Serbia

- International Monetary Fund. (2012). Word Economic Outlook. Washington, DC., United States of America: International Monetary Fund, Publication Services

- Swiss Re. (2012). European Insurance Report 2012, Customers for Life. Zurich, Switzerland

- Business Info Group. (2012). Banks and insurance in Serbia 2001-2011. Belgrade, Serbia

- Ministry of Finance and Economy. (2013). Fundamental macroeconomic indicators

In accordance with the purpose of the research, the authors tested the following hypotheses:

$\mathrm{H} 1$ : Existing linear trend of life insurance premium is sufficient for the further development of the life insurance market of the Republic of Serbia.

$\mathrm{H}$ 2: There is statistically significant influence of net income on life insurance premium in the Republic of Serbia.

The linear trend can be adjusted to the time series of life insurance premium amount, since the value of this parameter on average has a constant growth. In this paper authors used the method of standard error estimation according to which an optimal trend is the one with the lowest average deviations of actual values of the time series under consideration from the theoretical values - trend lines (Savić, 2005.) 
Munitlak Ivanović O. et al.: Analysis of Life Insurance Premium in Regard to Net...

Linear trend equation is:

$\hat{y}_{i}=a+b x$

where:

$$
\sum_{i=1}^{n} y_{i}=n a ; \sum_{i=1}^{n} x_{i} y_{i}=b \sum_{i=1}^{n} x_{i}^{2}
$$

During further considerations dependency of two variables was explored: the amount of life insurance premium and average net income. On the basis of the regression analysis, which shows the shape of relation between the dependent and independent variable a prediction was made on the value of dependent variable (amount of the premium) with certain values of the independent variable (average net income). The method of least squares was used for the evaluation of regression equation parameters which evaluates variables so that the deviations from the slope are the smallest. (BiljanAugust, Pivac, Štambuk, 2007.) The regression equation is the following:

$$
\hat{Y}=\hat{\beta}_{0}+\hat{\beta}_{1} X
$$

Pearson correlation coefficient was used to measure correlation between random variables:

$r=\frac{\sum_{i=1}^{n} X_{i} Y_{i}-n \bar{X} \bar{Y}}{n \sigma_{x} \sigma_{y}}$

Essentially, the goal of the regression analysis is to find an analytical expression of connection between the regressand (life insurance premium) and the regressor (average net income) with the prediction of values of the dependent variable that can be made against the specified values of independent variables.

\section{Results and discussion}

\subsection{Serbia and the region}

Insurance market in Serbia is characterized by a relative stability and it has a continuous but still insufficient growth. If the neighboring countries and the European Union are taken into consideration, it is obvious that this sector is 
Munitlak Ivanović O. et al.: Analysis of Life Insurance Premium in Regard to Net...

still underdeveloped and that it is well below neighboring countries except in the case of Romania.

Table 1. Total amount of premium in 2011

\begin{tabular}{|l|c|c|c|c|c|c|c|}
\hline Country/Region & Rank & $\begin{array}{c}\text { Amount of } \\
\text { premium } \\
\text { (million } \\
\text { USD) }\end{array}$ & $\begin{array}{c}\text { Global } \\
\text { market } \\
\text { share (in \%) }\end{array}$ & Rank & $\begin{array}{c}\text { Premium } \\
\text { asGDP \% }\end{array}$ & Rank & $\begin{array}{c}\text { Premium per } \\
\text { capita (in } \\
\text { USD) }\end{array}$ \\
\hline Europe & & $1,650,866$ & 35.93 & & 7.06 & & $1,885.7$ \\
\hline EU27 & $1,498,677$ & 32.61 & & 7.89 & & $2,756.7$ \\
\hline $\begin{array}{l}\text { Western } \\
\text { Europe }\end{array}$ & $1,557,927$ & 33.90 & & 7.93 & & $2,947.1$ \\
\hline $\begin{array}{l}\text { Central and } \\
\text { Eastern Eu- } \\
\text { rope }\end{array}$ & 79. & 781 & 0.02 & 65. & 1.7 & 66. & 107 \\
\hline Serbia & 59. & 1,711 & 0.04 & 51. & 2.7 & 47. & 389 \\
\hline Croatia & 55. & 2,607 & 0.06 & 71. & 1.5 & 65. & 122 \\
\hline Romania & 67. & 1,131 & 0.02 & 57. & 2.1 & 63. & 151 \\
\hline Bulgaria & 43. & 6,879 & 0.15 & 55. & 2.3 & 36. & 608 \\
\hline Greece & 50. & 3,008 & 0.07 & 23. & 5.9 & 28. & 1,464 \\
\hline Slovenia & 48. & 3,964 & 0.09 & 50. & 2.8 & 46. & 397 \\
\hline Hungary & & & & & 2.62 & & 286.7 \\
\hline
\end{tabular}

Source: Swiss Re. (2012). Sigma No3/2012, World Insurance in 2011. Zurich, Switzerland: Author.

If the total insurance premium in 2011 is considered, Serbia is ranked $79^{\text {th }}$ and when compared to the neighboring countries it has the worst position with a premium of 781 million USD. According to this indicator of insurance market development, Greece (ranked $43^{\text {rd }}$ ) holds the best position in the region.

According to the criterion of premium participation in GDP (insurance penetration) in 2011, Serbia is ranked $65^{\text {th }}$ with $1.7 \%$, while in 2010 it was ranked $64^{\text {th }}$. In the case of the EU this indicator is $7.89 \%$. If the situation in the Central and Eastern European countries (2.62\%) is taken into consideration, it can be concluded that this indicator is satisfactory. Among the analyzed countries in the region, the highest value of the premium participation in GDP has Slovenia (5.9\%), and the lowest Romania (1.5\%).

According to the criterion of premium per capita (insurance density), with 107 USD in 2011, Serbia is ranked $66^{\text {th }}$ in the world, the same as in 2010. If we compare this result to the EU countries (2,756.7 USD), we can see that this 
Munitlak Ivanović O. et al.: Analysis of Life Insurance Premium in Regard to Net...

indicator is significantly lower in Serbia than the average values in the EU and that the insurance sector in Serbia is still insufficiently developed. Among the considered countries in the region, Slovenia with 1,464 USD (ranked $28^{\text {th }}$ ) is the best ranked country in the region. Romania with 122 USD (ranked 65 ${ }^{\text {th }}$ ) is closest to Serbia. The best ranked is Switzerland with 8,012 USD, followed by Germany and Luxembourg.

Participation of life insurance premium in the total insurance premium is a significant indicator of the sector development. This indicator has a very low value in Serbia (16.1\%), especially when it is compared to Greece $(42.6 \%)$ and Hungary (55.3\%). This indicator is lower only in Bulgaria (14.4\%). If we consider only the life insurance, Serbia holds $80^{\text {th }}$ position with 126 million USD premium in 2011, which is relatively better situation than in 2010 when the premium was 111 million USD. This form of insurance in the region is best developed in Greece ( $38^{\text {th }}$ position) and Hungary $\left(41^{\text {st }}\right.$ position). According to this criterion, Bulgaria (163 million USD) and Croatia (455 million USD premium) are closest to Serbia.

Table 2. Amount of life insurance premium

\begin{tabular}{|l|c|c|c|c|}
\hline \multirow{2}{*}{ Country } & \multirow{2}{*}{ Rank } & \multicolumn{2}{|c|}{$\begin{array}{c}\text { Premium amount } \\
\text { (million USD) }\end{array}$} & $\begin{array}{c}\text { Participation in } \\
\text { total premium } \\
\text { (\%) }\end{array}$ \\
\cline { 3 - 4 } & & 2011 & 2010 & 16.1 \\
\hline Serbia & 80. & 126 & 111 & 26.6 \\
\hline Croatia & 60. & 455 & 447 & 21.2 \\
\hline Romania & 57. & 554 & 512 & 14.4 \\
\hline Bulgaria & 77. & 163 & 151 & 42.6 \\
\hline Greece & 38. & 2,931 & 3,012 & 31.3 \\
\hline Slovenia & 49. & 942 & 870 & 55.3 \\
\hline Hungary & 41. & 2,193 & 2,136 & \\
\hline
\end{tabular}

Source: Swiss Re. (2012). Sigma No3/2012, World Insurance in 2011. Zurich, Switzerland: Author.

It is realistic to expect that the life insurance sector in Serbia in the following period will grow faster and that its participation in the total insurance premium will get closer to the values in other countries in the region. It should be noted that in Serbia it is not allowed to sell the so called „unit linked“ products, specific types of investment products sold by life insurance companies. This is one of the factors of greater growth and bigger participation of this type of 
Munitlak Ivanović O. et al.: Analysis of Life Insurance Premium in Regard to Net...

insurance in other countries. This is especially true for the market of Hungary (Business Info Group, 2012.)

From the point of view of criterion of insurance market condition in the region, it is necessary to consider macroeconomic indicators as well, especially in the field of life insurance. Table 3 presents the current condition in the stated countries of the region. It shows that the unemployment rate in Serbia, $24.4 \%$, is far higher than in other countries. According to this indicator, Greece is closest to Serbia with the unemployment rate of $17.3 \%$, while in other countries it does not exceed $10 \%$. Serbia also notes the highest inflation rate in the region (at the end of 2011 annual inflation rate was 7\%, and the average inflation rate was 11\%).

Table 3. Macroeconomic indicators (2011)

\begin{tabular}{|l|c|c|c|c|}
\hline \multicolumn{1}{|c|}{ Country } & $\begin{array}{c}\text { Population } \\
\text { (million) }\end{array}$ & $\begin{array}{c}\text { Real GDP } \\
\text { (change in \%) }\end{array}$ & $\begin{array}{c}\text { Annual inflation rate } \\
\text { (December, \%) }\end{array}$ & $\begin{array}{c}\text { Unemployment } \\
\text { rate (\%) }\end{array}$ \\
\hline Serbia & 7.3 & 1.6 & 7.0 & 24.4 \\
\hline Croatia & 4.4 & 0.0 & 2.0 & 13.7 \\
\hline Romania & 21.4 & 2.5 & 3.1 & 7.4 \\
\hline Bulgaria & 7.5 & 1.7 & 2.0 & 11.3 \\
\hline Greece & 11.3 & -6.9 & 2.2 & 17.3 \\
\hline Slovenia & 2.1 & 0.6 & 2.1 & 8.2 \\
\hline Hungary & 10.0 & 1.7 & 4.1 & 11.0 \\
\hline
\end{tabular}

Source: Swiss Re. (2012). Sigma No3/2012, World Insurance in 2011. Zurich, Switzerland: Author. \& International Monetary Fund. (2012). Word Economic Outlook. Washington, DC., United States of America: International Monetary Fund, Publication Services.

\subsection{Life insurance market in Serbia}

According to the report of the National Bank of Serbia for 2011, in Serbia insurance activities were performed by 28 insurance companies, and the total amount of premiums was 709 million USD. Participation of non-life insurance in the premium structure was $82.6 \%$, and participation of life insurance was $17.4 \%$. Non-life insurance premium in Serbia has substantially larger participation in total premium than in the EU countries. This is a consequence of a high unemployment rate and low living standard. Insurance market development in Serbia, measured by the total premium shows that the total premium in 2011 , when compared to premium in 2010 , nominally grew by $1.4 \%$, but noted real decrease of $5.2 \%$. Participation of life insurance in the premium 
Munitlak Ivanović O. et al.: Analysis of Life Insurance Premium in Regard to Net...

structure increased from $16.5 \%$ in 2010 to $17.4 \%$ in 2011 , because of the growth of $6.8 \%$ in relation to the previous year.

Life insurance premium has a constant growth in the last six years (Fig.1), even with the influence of world economic crisis. This can be explained by the fact that this type of insurance has very low development rate. The crisis did not primarily have influence on this insurance market segment (Business Info Group, 2012). All countries in transition have significantly bigger market share of non-life insurance than life insurance and this type of insurance is characterized by a slower growth. In 2005 percentage of life insurance share was $9.5 \%$, and in 2011 it was $17.4 \%$.

Figure1. Life insurance premium 2005-2011 (million USD)

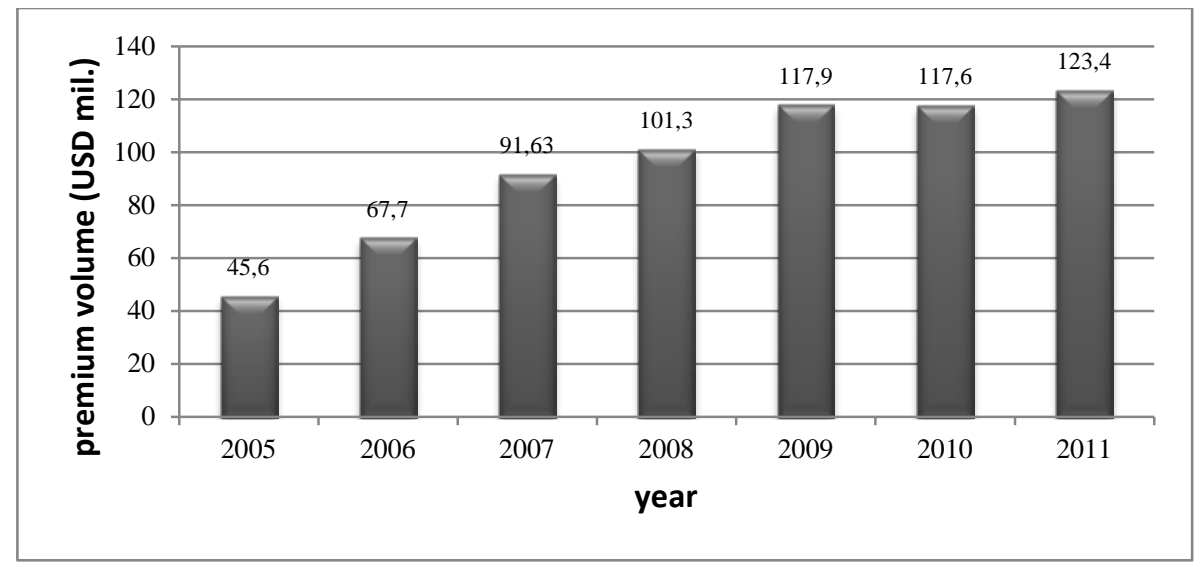

Source: National Bank of Serbia. (2012). Insurance sectors in Serbia, report for 2011. Belgrade, Serbia: Author

The share of life insurance in the total of all insurances is a significant indicator of the development of the entire insurance sector. A potential for intensified growth can be expected in the further financial market development. In the balance sheet of the financial sector for 2011, banks had a market share of $92.4 \%$, and insurance companies $4.4 \%$. If the previous years are considered as well, it is clear that banks have the most important role on the financial market in Serbia from the perspective of balance-sheet total and the number of employed persons.

\subsection{Data Analysis}

The value of life insurance premium on average has a constant growth, and the linear trend can be adjusted to this time series. Table 4 shows the amount of premium in the period $2004-2011$ (Y) and theoretical values of the amount in relation to the calculated linear trend. 
Munitlak Ivanović O. et al.: Analysis of Life Insurance Premium in Regard to Net...

Table 4. Linear trend parameters

\begin{tabular}{|c|l|l|l|l|l|}
\hline Year $(X)$ & $\begin{array}{c}Y \text { (premi- } \\
\text { um } \\
\text { amount, in } \\
\text { O00) }\end{array}$ & $\begin{array}{c}x_{i} \text { (year } \\
\text { mark) }\end{array}$ & \multicolumn{1}{|c|}{$x_{i} y_{i}$} & $x_{i}^{2}$ & $\hat{y}_{i}$ (in 000) \\
\hline 2004 & $1,605,000$ & -3.5 & $-5,617,500$ & 12.25 & $1,658,583.3$ \\
\hline 2005 & $3,153,000$ & -2.5 & $-7,882,500$ & 6.25 & $2,769,309.5$ \\
\hline 2006 & $3,812,000$ & -1.5 & $-5,718,000$ & 2.25 & $3,880,035.7$ \\
\hline 2007 & $4,597,000$ & -0.5 & $-2,298,500$ & 0.25 & $4,990,761.9$ \\
\hline 2008 & $5,922,000$ & 0.5 & $2,961,000$ & 0.25 & $6,101,488.1$ \\
\hline 2009 & $7,314,000$ & 1.5 & $10,971,000$ & 2.25 & $7,212,214.3$ \\
\hline 2010 & $8,646,000$ & 2.5 & $21,615,000$ & 6.25 & $8,322,940.5$ \\
\hline 2011 & $9,320,000$ & 3.5 & $32,620,000$ & 12.25 & $9,433,666.7$ \\
\hline$\Sigma$ & $44,369,000$ & 0 & $46,650,500$ & 42 & $44,369,000$ \\
\hline
\end{tabular}

Source:Author

By inserting values in (2) and (1) parameters are obtained in the linear trend equation.

$$
\hat{y}_{i}=5546125000+1110726190 x
$$

The starting point of the linear trend is $31 / 12 / 2007$. The unit for $\mathbf{x}$ is one year, and the unit for $\mathbf{y}$ is the premium amount in RSD.

Parameter $\mathbf{a}=5,546,125,000$ shows a trend value at the starting point, that is, the theoretical value of premium amount as of $31 / 12 / 2007$. Parameter $\mathbf{b}=1,110,726,190$ shows that the premium amount increased every year on average by 1,11 billion RSD.

The standard error, that is, an average deviation of actual data on premium volume from the trend line is $279,770,956$ RSD, and coefficient of variation shows that the standard error is $5.04 \%$ of the time series arithmetic mean $(5,546,125,000$ RSD).

If a corresponding value for year designation is inserted in the linear trend equation, a trend value for 2013 and 2015 can be estimated, which is the expected value of premium volume for the year under consideration. The results are as follows:

$y_{2013}=11.7$ billion RSD

$y_{2015}=13.9$ billion RSD 
Munitlak Ivanović O. et al.: Analysis of Life Insurance Premium in Regard to Net...

With a probability of $95 \%$, it can be expected that the premium volume in 2013 will be in the range between 10.97 and 12.34 billion RSD, and in 2015 in the range between 13.2 and 14.56 billion RSD. Since the level of life insurance premium in Croatia and Romania in 2011 reached the level of 455 and 544 million USD respectively (which is approximately 33.4 billion RSD and 39.9 billion RSD respectively, at the average exchange rate of the National Bank of Serbia for 2011), it is clear that such a trend will not lead to the expected development and that a more intensified growth is necessary. Therefore, the hypothesis $\mathrm{H} 1$ is rejected.

The aim of the regression analysis is to determine whether and up to what extent there is a dependency between the considered variables (volume of premium and average net income).

Table 5. Amount of premium and average net income (in RSD)

\begin{tabular}{|c|c|c|}
\hline Year & $\begin{array}{c}\text { Amount of premium } \\
\text { (in 000) }\end{array}$ & Average net income \\
\hline 2004 & $1,605,000$ & 14,103 \\
\hline 2005 & $3,153,000$ & 21,707 \\
\hline 2006 & $3,812,000$ & 27,759 \\
\hline 2007 & $4,597,000$ & 32,746 \\
\hline 2008 & $5,922,000$ & 31,733 \\
\hline 2009 & $7,314,000$ & 34,142 \\
\hline 2010 & $8,646,000$ & 37,976 \\
\hline 2011 & $9,320,000$ & 40,872 \\
\hline
\end{tabular}

Source: National Bank of Serbia. (2012). Insurance sector in Serbia, report for 2011. Belgrade, Serbia: Author \& Ministry of Finance and Economy (2013). Fundamental indicators of macroeconomic developments. Taken from:

http://mfp.gov.rs/UserFiles/File/tabele/2013\%20januar/Tabela\%201\%20Osnovni\%20 makroekonomski\%20indikatori.pdf

Dispersion diagram (Fig. 2) shows pairs of values of the variables under consideration. There are positive and negative deviations from the slope, as a consequence of influences of other random variables. In this example, on the basis of the dispersion diagram, it can be concluded that there is a statistic positive connection between variables under consideration, that is, growth of one variable follows the growth of the other observed variable. 
Munitlak Ivanović O. et al.: Analysis of Life Insurance Premium in Regard to Net...

Figure 2: Dispersion diagram

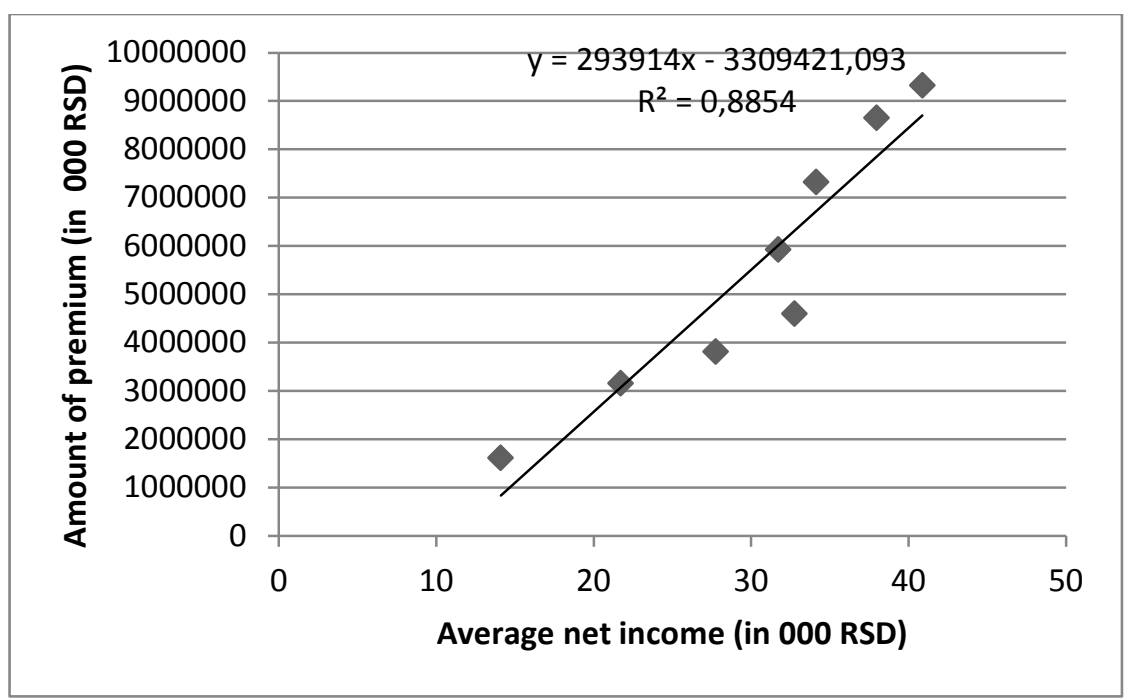

Source:Author

Regression analysis results are presented in Table 6:

Table 6: Regression analysis results

\begin{tabular}{|c|c|c|c|c|c|c|c|}
\hline \multicolumn{4}{|l|}{$r$} & \multicolumn{4}{|c|}{0.940953} \\
\hline \multicolumn{4}{|l|}{$r^{2}$} & \multicolumn{4}{|c|}{0.885392} \\
\hline \multicolumn{4}{|l|}{ Observation } & \multicolumn{4}{|l|}{8} \\
\hline ANOVA & $d f$ & SS & \multicolumn{3}{|l|}{ MS } & $F$ & Significance $F$ \\
\hline Regression & 1 & 46293237222456.7 & \multicolumn{3}{|c|}{46293237222456.7} & 46.35252479 & 0.000492155 \\
\hline Residual & 6 & 5992325652543.26 & \multicolumn{3}{|c|}{998720942090.544} & & \\
\hline \multirow[t]{2}{*}{ Total } & 7 & 52285562875000 & & & & & \\
\hline & & Coefficients & \multicolumn{2}{|c|}{ Standard Error } & & $t$-Stat & $P$-value \\
\hline \multicolumn{2}{|l|}{ Intercept } & -3309421 & \multicolumn{2}{|c|}{1347839.892} & & 455351791 & 0.04943 \\
\hline \multicolumn{2}{|l|}{$X$ variable } & 293913.7 & \multicolumn{2}{|c|}{43170.10673} & & 308268854 & 0.000492 \\
\hline
\end{tabular}

Source:Author

The value of correlation coefficient $r=0.94$ indicates that there is a strong correlation between the observed variables. Coefficient of determination $r^{2}$ is 0.885 . This means that the model explains a $88.5 \%$ variance of the dependent variable i.e. premium amount, that is $88.5 \%$ of the sum of squares of deviation of the dependent variable from the arithmetic mean is explained by the regression model. 
Munitlak Ivanović O. et al.: Analysis of Life Insurance Premium in Regard to Net...

Table 6 shows the result of the variance analysis, that is of F-test of the null hypothesis, $r^{2}=0$, with degrees of freedom 1 and 6 , against alternative hypothesis, $r^{2} \neq 0$. This model becomes statistically significant (Sig. $F<0,05$ ), which means that the null hypothesis at the significance level of $5 \%$ is rejected.

T-test shows if the variable gives a statistically significant contribution to the equation. The null hypothesis is that $\beta_{j}=0$, and the number of degrees of freedom is 6 , against alternative hypothesis is that $\beta_{j} \neq 0$. P-value is below 0.05 , meaning that the tested hypothesis that the average net income has no significant impact on the volume of life insurance premium is rejected at a $5 \%$ level.

According to the regression analysis results, hypothesis $\mathrm{H} 2$, that there is statistically significant influence of net income on life insurance premium in the Republic of Serbia, is confirmed.

The regression equation has the following form:

$Y=293913,7 X-3309421$

Regression coefficient $\beta_{1}$ shows that the amount of premium is increased by approximately 293,914 monetary units when the average net income is increased by one monetary unit.

If the average net income was increased from 40,872 RSD (the amount in 2011 ) to estimated 74,118 RSD, the amount of net income in the same year in Croatia, (converted in RSD at the official exchange rate of the National Bank of Serbia), life insurance premium would, according to this model, be approximately 21.8 billion RSD. With the assumption of income increase of 1.81 times, life insurance premium would be increased 2.34 times. However, the amount of life insurance in Croatia, with the stated average net income, is 125.5 billion RSD. This means that allocations for life insurance from the net income in the Republic of Serbia must be significantly increased together with the increase of net income. The aim of this is to bring nearer the development rate of this segment of insurance market to developed markets of the European Union.

\section{Conclusions}

The main point of this paper was analysis and projection of life insurance premium on the basis of linear trend parameters and correlation degree between the average net income and amount of life insurance premium. This 
Munitlak Ivanović O. et al.: Analysis of Life Insurance Premium in Regard to Net...

pointed to the necessity of intensified development of life insurance market in Serbia. The paper presents projection of the amount of insurance premium on the basis of linear trend parameters and shows statistic relation between the average net income and the amount of premium. In this way it is explained how the increase in net income will influence the development of life insurance market.

During the period 2004 to 2011 the average growth of premium was 1.11 billion RSD. Projection on the basis of a linear trend determined that premium growth degree needs to be greatly intensified, so that the market performances reach the level of developed life insurance markets.

There is a significant statistic relation between the average net income and the amount of life insurance premium which indicates the fact that it is necessary primarily to increase the living standard. According to the regression model, the increase in income by one monetary unit does not result in a satisfactory increase of premium amount. This proves that the allocation for life insurance from the net income needs to be significantly increased, so that life insurance per capita can be increased and life insurance market can be developed.

Apart from other quantitative factors, in respect of potential development of life insurance, it is necessary to consider qualitative determinants as well, such as awareness of life insurance benefits, insurers' habits, approach to future insurers, etc. However, the key determinate is the average net income, which was proven by a high correlation degree between life insurance premium amount and average net income.

The process of creating stable system of life insurance and promoting trust of public in this sector are in progress. It is necessary to monitor all participants in order to secure protection of users. Development of life insurance will greatly depend on the economy, but also on the readiness of the society to develop in this field, which has a potential to develop with constant education of users.

In conditions of a low living standard, it cannot be expected that the employees participate substantially in programs of life insurance. World economic crisis caused great consequences in all micro and macro aspects, including insurance market. The increase in the living standard and recovery of economy create conditions for significant development of life insurance.

Although Serbia has poor indicators in comparison to the developed European countries and the countries in the region, it has a development potential for the insurance market which has not sufficiently been used. Improvement of life insurance would improve the position of insurance companies in the financial market which would lead to a further development of life insurance and insurance in general. 
Munitlak Ivanović O. et al.: Analysis of Life Insurance Premium in Regard to Net...

\section{References}

Avdalović, A. (2007). Principi osiguranja. Novi Sad, Serbia: FTN izdavaštvo.

Beck, T., \& Webb, I. (2003). Economic, Demographic, and Institutional Determinants of Life Insurance Consumption across Countries. The World Bank Economic Review, 17(1), 51-88. doi:10.1093/wber/lhg011

Biljan-August, M., Pivac, S., \& Štambuk, (2007). Upotreba statistike u ekonomiji. Rijeka, Hrvatska: Ekonomski fakultet Sveučilišta u Rijeci.

Burnett, J.J., \& Palmer, B.A. (1984). Examining Life Insurance Ownership through Demographic and Psychographic Characteristics. Journal of Risk and Insurance, 51(3), 453. doi:10.2307/252479

-Business Info Group. (2012). Banke i osiguranja u Srbiji 2001-2011. Beograd, Srbija: Autor.

Hung, C.C., \& Chiang, C.L. (2012). Non-Linearity Between Life Insurance and Economic Development: A Revisited Approach. The Geneva Risk and Insurance Review, 37, 223-257. doi:10.1057/grir.2011.10.

-International Monetary Fund. (2012). World economic outlook. Washington, DC: United States of America: International Monetary Fund, Publication Services.

Jeremić, L., \& Paunović, M. (2011). Komparativna analiza tržišta osiguranja u Evropskoj uniji, Srbiji i državama u regionu.Singidunum revija, 8(1), 17-26.

-Ministarstvo finansija i privrede Republike Srbije. (2013). Osnovni indikatori makroekonomskih kretanja. Retrieved from http://mfp.gov.rs/UserFiles/File/tabele/2013\%20januar/Tabela\%201\%20Osnovni \%20 makroekonomski\%20indikatori.pdf

-Narodna banka Srbije. (2012). Sektor osiguranja u Srbiji, izveštaj za III kvartal 2012. godine. Beograd, Srbija: Autor.

-Narodna banka Srbije. (2012). Sektor osiguranja u Srbiji, izveštaj za 2011. godinu. Beograd: Autor.

Savić, M. (2005). Poslovna statistika. Subotica, Srbija: Minerva.

-Swiss Re. (2012). Europian Insurance Report 2012, Customers for Life. Zurich, Switzerland.

-Swiss Re. (2012). Sigma 03/2012, World Insurance in 2011. Zurich, Switzerland.

Službeni glasnik RS 55/04. (2004). Zakon o osiguranju, Beograd, Srbija: Autor. (2004).

Ward, D., \& Zurbruegg, R. (2000). Does Insurance Promote Economic Growth? Evidence from OECD Countries. Journal of Risk and Insurance, 67(4), 489-506. doi:10.2307/253847 